\title{
PERBANDINGAN EFEKTIVITAS TAMPON MINYAK BIJI JINTAN HITAM (Nigella sativa) DENGAN TAMPON RIVANOL 0,1\% TERHADAP GEJALA KLINIS OTITIS EKSTERNA AKUT
}

\author{
Ferdian Rifqy Nur Fachrudien ${ }^{1}$, M.N.Haitamy ${ }^{1}$, Andi Muh. Maulana ${ }^{1}$, Oke Kadarullah ${ }^{1}$ \\ ${ }^{I}$ Fakultas Kedokteran, Universitas Muhammadiyah Purwokerto \\ Email: ferdy41@live.com
}

\begin{abstract}
Acute external otitis is an external ear inflammatory disease including the distal portion of the earlobe to the proximal portion of the tympanic membrane caused by bacteria, fungi, or viruses. This disease has a rapid onset of inflammation with clinical symptoms such as itching, otalgia, edema, erythema, and otorrhea. Acute external otitis therapy is performed with antibiotic and topical anti-inflammatory treatment. Rivanol $0.1 \%$ was proven having the effectiveness to treat acute external otitis with long activity as an active antiseptic on alkaline $\mathrm{pH}$ that will bind to bacteria. Nigella sativa seed oil was proved having activity as a positive gram or negative anti-bacterial, anti-inflammatory and wound healing by increasing the growth of collagen fibers. To compare the effectiveness of acute external otitis on clinical symptoms using rivanol $0.1 \%$ tampon with Nigella sativa seed oil tampon. This study used post test design only randomized controlled group design with primary data was clinical symptoms score of nine subjects of acute external otitis patients. Subjects were divided into two treatment groups: four patients with rivanol $0.1 \%$ tampon and five patients with Nigella sativa tampons. Evaluation of clinical symptoms was performed on the third and fifth day of treatment. There were no differences on clinical symptoms during treatment between the two groups $(p=0.329)$, but there were improvements on clinical symptoms score between third and fifth day of treatment $(p=0.001)$ in each group. Nigella sativa oil has effectiveness in the treatment of acute external otitis but there was no significant difference with treatment using rivanol $0.1 \%$.
\end{abstract}

Keywords: Otitis externa, Nigella sativa, Rivanol $0.1 \%$

\section{ABSTRAK}

Otitis eksterna akut merupakan penyakit radang telinga luar meliputi bagian distal daun telinga sampai dengan bagian proximal membran timpani yang disebabkan oleh bakteri, jamur, maupun virus. Penyakit ini memiliki onset inflamasi yang cepat dengan gejala klinis berupa gatal, otalgia, edema, eritema, dan otorrhea. Terapi otitis eksterna akut dilakukan dengan pemberian antibiotik dan antiinflamasi topikal. Rivanol $0,1 \%$ terbukti memiliki efektivitas mengobati otitis eksterna akut dengan aktivitas panjang sebagai antiseptik aktif pada $\mathrm{pH}$ alkali yang akan berikatan dengan bakteri. Minyak biji Nigella sativa terbukti memiliki aktivitas sebagai antibakteri gram positif maupun negatif, antiinflamasi dan penyembuh luka dengan meningkatkan pertumbuhan serabut kolagen. Untuk membandingkan efektivitas penggobatan otitis eksterna akut terhadap gejala klinis menggunakan tampon rivanol $0,1 \%$ dengan tampon minyak biji Nigella sativa. Penelitian ini menggunakan desain post test only randomized controlled grup design dengan data primer yaitu skor gejala klinis sembilan subjek penderita otitis eksterna akut. Subjek dibagi menjadi dua kelompok terapi : empat penderita dengan tampon rivanol 0,1\% dan lima penderita dengan tampon Nigella sativa. Evaluasi gejala klinis dilakukan pada hari ketiga dan kelima pengobatan. Tidak ada perbedaan gejala klinis selama pengobatan antara kedua kelompok $(p=0.329)$, namun terdapat perbaikan skor gejala klinis antara hari ketiga dan hari kelima pengobatan $(p=0.001)$ di masing-masing kelompok.Minyak Nigella sativa memiliki efektifitas pada pengobatan otitis eksterna akut tetapi tidak terdapat perbedaan yang bermakna dengan pengobatan menggunakan rivanol $0,1 \%$.

Kata Kunci: Otitis eksterna, Nigella sativa, Rivanol 0,1\% 


\section{PENDAHULUAN}

Otitis eksterna merupakan penyakit radang pada telinga yang terbagi menjadi akut maupun kronis yang disebabkan oleh bakteri, jamur, maupun virus. Terjadinya otitis eksterna juga dapat disebabkan beberapa faktor seperti kelembaban, trauma, terdapat benda asing, perubahan $\mathrm{pH}$ dan alergi ${ }^{1,2}$.

Empat dari 1000 orang meliputi usia anak maupun dewasa mengalami otitis eksterna pertahunnya. Center for Disease Control and Prevention, juga melaporkan bahwa di Amerika kejadian sekitar 2,4 juta kunjungan pertahun yang terdiagnosis otitis eksterna di pusat kesehatan ${ }^{3,4}$

Kejadian otitis eksterna di Inggris selama 12 bulan pada individu yang berusia 5 sampai 64 tahun, dan insidensi meningkat pada usia lebih dari 65 tahun. Secara umum di dunia insidesi otitis eksterna belum diketahui namun, di negara tropis seperti Indonesia insidensi otitis eksterna ditemukan pada semua usia, dan angka kejadian yang tertinggi yaitu pada usia 7 hingga 12 tahun ${ }^{5,6}$.

Bakteri penyebab otitis eksterna yaitu Pseudomonas, Stretokokus, Staphylococcus aureus, dan Bakteroides. Otitis eksterna akut dapat diklasifikasikan menjadi otitis eksterna difusa dan otitis eksterna sirkumkripta terdapat perbedaan penyebab, letak peradangan dan gejala yang timbul dari keduanya, pada otitis eskterna difusa disebabkan infeksi bakteri golongan Pseudomonas, Escherichia coli, Staphylococcus albus, dan sebagainya sedangakan otitis eksterna sirkumkripta disebabkan bakteri Staphylococus aureus dan Staphylococus albus 7,8 .

Berbagai macam pengobatan yang dapat diberikan untuk otitis eksterna, terapi biasanya tergantung dari keadaan telinga. Jika sudah terdapat abses atau furunkel dapat dilakukan aspirasi ataupun insisi, untuk pengbotan lokal dapat diberikan antibiotik bentuk salep seperti polymixin B atau bacitrasin, atau antiseptik (asam asetat 2-5\% dalam alkohol). Sebagai antiseptik rivanol $0,1 \%$ banyak digunakan karena sederhana, murah, dan banyak di Puskesmas serta memiliki efek yang panjang sebagai antiseptik yang aktif pada $\mathrm{pH}$ alkali yang akan berikatan dengan bakteri ${ }^{9,10}$.

Tanaman herbal telah digunakan untuk pengobatan penyakit di berbagai negara, Salah satunya yaitu jintan hitam (Nigella sativa) telah banyak digunakan di Eropa Selatan, Afrika Utara, Asia Selatan dan Asia Barat Daya. Ekstrak metanol Nigella sativa menunjukan adanya efek penghambat bakteri gram positif maupun negative antara lain Bacillus subtilis, Staphylococus aureus, Pseudomonas aeruginosa, Salmonella typhi ${ }^{11,12}$.

Aktivitas antimikroba minyak atsiri Nigella sativa lebih besar jika dikombinasi dengan antibiotik. Antiinflamasi juga terdapat pada minyak Nigella sativa yang memiliki aktivitas menghambat siklooksigenase dan lipo-oksigenase yang berfungsi sebagai mediator inflamasi sehingga dapat mencegah biosintesis prostaglandin dan leukotrien. Sebagai penyembuh luka ekstrak biji Nigella sativa yang digunakan secara topikal pada kulit yang terinfeksi staphylococcus sembuh dengan sempurna dengan menurunkan total dan absolut differential White blood cell (WBC) count, infeksi lokal, inflamasi, perluasan bakteri, dan kerusakan jaringan ${ }^{13,14,15}$.

Nigella sativa telah terbukti memiliki efek sebagai antiinflamasi dan antiseptik serta rivanol $0,1 \%$ telah dibuktikan keefektifannya sebagai antiseptik pada penggobatan otitis eksterna akut. 


\section{METODE}

Penelitian dilakukan menggunakan analisis eksperimental dengan rancangan post test only randomized controlled grup design. Total sampel diambil secara prospektif selama periode 22 Januari sampai enam Maret 2018 kemudian dibagi menjadi dua kelompok yaitu penderita otitis eksterna yang diberi pengobatan dengan rivanol $0,1 \%$ dan penderita otitis eksterna yang diberi pengobatan dengan minyak biji Nigella sativa. Penderita harus tergolong dengan kriteria inklusi yaitu bersedia menjadi responden dan telah menandatangani lembar informed consent, otitis eksterna yang berlangsung kurang dari tujuh hari, berumur lebih dari 10 tahun dan kriteri eksklusi yaitu penderita otitis media, diabetes mellitus, telah mendapat antibiotika sekurang-kurangnya tujuh hari sebelum pengobatan. masing-masing perlakuan diberikan sebanyak tiga kali sehari.

Penderita diberitahu untuk mencatat setiap keluhan yang timbul selama penggobatan. Penderita juga diberitahu agar menjaga kebersihan telinga dan menjaga liang telinga tidak kemasukan air. Kontrol kembali ke Rumah Sakit pada hari ketiga dan kelima. Penderita diminta agar mencatat semua keluhan selama pengobatan, jika keluhan yang dirasakan semakin buruk maka penderita harus melakukan kontrol ke dokter segera mungkin. Data yang diperoleh akan dianalisis dengan menggunakan software pengolah data statistik, uji normalitas menggunakan Shapiro-Wilk dilanjutkan dengan uji t tidak berpasangan, jika data tidak terdistribusi normal maka akan dilakukan uji Mann Whitney

\section{HASIL}

Penderita otitis eksterna yang datang berobat ke poliklinik THT RSI Purwokerto dan RS PKU Muhammadiyah Gombong dari pada 22 januari 2018 sampai 6 maret 2018, berjumlah sembilan pasien dikelompokkan secara acak menjadi dua kelompok yaitu kelompok rivanol $0,1 \%$ dan kelompok minyak Nigella sativa dengan umur termuda adalah 13 tahun dan umur tertua adalah 75 tahun, enam penderita lakilaki dan tiga perempuan, berdasar skor gejala klinis otitis eksterna didapatkan hasil sebagai berikut:

Tabel 1. Distribusi frekuensi usia dan jenis kelamin penderita otitis eksterna

\begin{tabular}{cccc}
\hline Usia & Frekuensi & \multicolumn{2}{c}{ Jenis Kelamin } \\
\cline { 3 - 4 } & & Laki-laki & perempuan \\
\hline $5-11$ & & 2 & 2 \\
$12-25$ & 4 & 2 & 1 \\
$26-45$ & 2 & 1 & \\
$46-65$ & 2 & 1 & \\
$>65$ & 1 & & \\
\hline
\end{tabular}


jenis kelamin penderita otitis eksterna

Tabel 1 menunjukkan jumlah frekuensi penderita otitis eksterna pada rentan umur lima sampai $>65$ tahun, frekuensi terbanyak adalah pada rentan umur 12-25 tahun dan perbandingan berdasarkan terbanyak adalah laki-laki dengan jumlah enam penderita sedangkan jumlah pada jenis kelamin perempuan yaitu tiga penderita.

Tabel 2. Distribusi skor gejala klinis penderita otitis eksterna

\begin{tabular}{|c|c|c|c|c|c|c|}
\hline \multirow[t]{2}{*}{ Tampon } & \multicolumn{2}{|c|}{ hari ke-1 } & \multicolumn{2}{|c|}{ hari ke-3 } & \multicolumn{2}{|c|}{ hari ke-5 } \\
\hline & skor & keterangan & skor & keterangan & skor & keterangan \\
\hline R 1 & 3 & $\begin{array}{c}\text { kurang } \\
\text { baik }\end{array}$ & 4 & baik & 5 & Baik \\
\hline R 2 & 3 & $\begin{array}{c}\text { kurang } \\
\text { baik }\end{array}$ & 3 & $\begin{array}{c}\text { kurang } \\
\text { baik }\end{array}$ & 6 & sangat baik \\
\hline R 3 & 5 & baik & 5 & baik & 6 & sangat baik \\
\hline R 4 & 4 & baik & 4 & baik & 6 & sangat baik \\
\hline N 1 & 5 & baik & 5 & baik & 8 & sangat baik \\
\hline N 2 & 5 & baik & 5 & baik & 8 & sangat baik \\
\hline N 3 & 3 & $\begin{array}{c}\text { kurang } \\
\text { baik }\end{array}$ & 3 & $\begin{array}{c}\text { kurang } \\
\text { baik }\end{array}$ & 8 & sangat baik \\
\hline N 4 & 3 & $\begin{array}{c}\text { kurang } \\
\text { baik }\end{array}$ & 8 & sangat baik & 8 & sangat baik \\
\hline N 5 & 3 & $\begin{array}{c}\text { kurang } \\
\text { baik }\end{array}$ & 3 & $\begin{array}{c}\text { kurang } \\
\text { baik }\end{array}$ & 7 & sangat baik \\
\hline
\end{tabular}

Keterangan : R (penderita dengan perlakuan rivanol) $\mathrm{N}$ (penderita dengan perlakuan Nigella sativa)

Tabel 2. menunjukkan penderita otitis eksterna dengan gejala klinis pada hari ke-1, ke-3 dan ke-5 pemeriksaan.

Gambar 1. menunjukkan nilai rerata pada hari pertama yaitu 3,75 untuk kelompok rivanol dan 3,80 untuk kelompok Nigella sativa, pada hari ketiga yaitu 4,0 untuk kelompok rivanol dan 4,80 untuk kelompok Nigella sativa, dan pada hari kelima yaitu 5,75 untuk kelompok rivanol dan 7,80 untuk kelompok Nigella sativa dari data tersebut terdapat perubahan skor gejala pada hari ketiga dan kelima. 


\section{Gambar 1. Skor gejala klinis perlakuan obat pada hari pengamat}

Skor Gejala Klinis Perlakuan Obat pada Hari Pengamatan

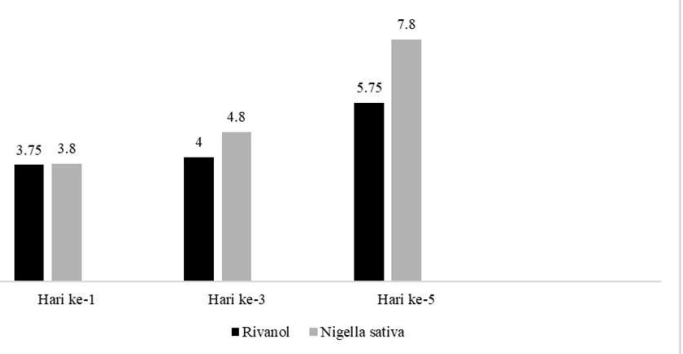

Tabel 3. menunjukkan skor gejala klinis pada pemberian rivanol dan Nigella sativa dengan uji statistik menggunakan Mann Whitney didapatkan hasil bahwa nilai rerata dan standar deviasi pada kelompok rivanol yaitu $4.50 \pm 1.168$ dan nilai rerata dan standar
Tabel 3. Rerata dan standar deviasi skor gejala klinis

\begin{tabular}{lccc}
\hline & $\mathrm{n}$ & Rerata $\pm \mathrm{SD}$ & $p$ \\
\hline Rivanol & 12 & $4.50 \pm 1.168$ & 0.329 \\
Nigella & 15 & $5.47 \pm 2.167$ & \\
sativa & & & \\
\hline
\end{tabular}

deviasi pada kelompok Nigella sativa yaitu $5.47 \pm$ 2.167 dapat disimpulkan bahwa tidak ada perbedaan skor gejala klinis antara kedua kelompok karena nilai $p>0,05$.

Tabel 4. Rerata dan standar deviasi perbandingan gejala klinis berdasarkan hari pengobatan

\begin{tabular}{cccc}
\hline & $\mathrm{n}$ & Rerata \pm SD & $p$ \\
\hline Hari ke-1 & 9 & $3.78 \pm 0.972$ & \\
Hari ke-3 & 9 & $4.44 \pm 1.590$ & 0.001 \\
Hari ke-5 & 9 & $6.89 \pm 1.167$ & \\
\hline
\end{tabular}

Tabel 4. menunjukkan bahwa dari uji Kruskal Wallis antara skor gejala klinis antara kedua kelompok pada hari pertama, ketiga, dan kelima didapatkan hasil

\section{PEMBAHASAN}

Pengobatan otitis eksterna dengan menggunakan rivanol pada 33 penderita pada evaluasi pengobatan hari ketiga didapatkan hasil 20 penderita sembuh dan 13 tidak sembuh, kemudian dievaluasi kembali pada hari kelima pengobatan didapatkan hasil bahwa 29 penderita sembuh dan empat penderita tidak sembuh hal ini sesuai dengan penelitian ini karena terjadi proses penyembuhan dan penurunan gejala klinis bahwa terdapat perbedaan yang signifikan antar hari dengan nilai $p<0,05$.

terhadap penderita otitis eksterna dengan pengobatan menggunakan rivanol. Rivanol yang memiliki sifat antiseptik bakteri gram positif dan negatif serta anti jamur dengan menghambat sintesis DNA. Nigella sativa memiliki kandungan zat aktif yaitu Thymoquinone yang telah terbukti sebagai antiseptik spektrum luas, sediaan minyak Nigella sativa terbukti menghambat pertumbuhan bakteri seperti B. cereus, 
B. subtilis, S. aureus, S. epidermis, E. coli, and P. aeruginosa ${ }^{10,16}$.

Nigella sativa juga dilaporkan memiliki efek yang sinergis dengan streptomycin, gentamicin, dan additive effect dengan spectinomycin, erythromycin, tobramycin, doxycycline, chloramphenicol, nalidixic acid, ampicillin, lincomycin dan co-trimoxazole serta berhasil mengobati non-fatal subcutaneous staphylococcal infection pada percobaan menggunakan mencit, ekstrak Nigella sativa juga menunjukkan hasil yang sama dengan mupirocin secara topikal pada pengobatan neonatus dengan infeksi staphylococcal pustular skin ${ }^{17}$. 
efek Nigella sativa sebagai penyembuh infeksi dengan menurunkan differential leukocytes (WBC) counts infeksi lokal dan inflamasi, perluasan bakteri, kerusakan jaringan, dan produksi radikal bebas, serta meningkatkan fibroblast growth factor (FGF) dan transforming growth factor beta (TGF- $\beta$ ). Aktifitas antiinflamasi juga terdapat dalam Nigella sativa dengan menurunkan aktivitas $C$-reactive protein serum levels pada inflamasi akut dan menghambat cyclooxygenase and 5-lipoxygenase pada jalur arachidonate ${ }^{17,18}$.

Hal tersebut sinergis dengan hasil perubahan gejala klinis pada hari ketiga dan kelima kelompok Nigella sativa dan jumlah penderita yang mengalami edema pada hari kelima pengobatan lebih banyak pada kelompok rivanol dibanding kelompok Nigella sativa.

Aktivitas antifungal yang menghambat pertumbuhan Aspergillus flavus, Aspergilus fumigates, Issatchenkia orientalis, Criptococcus laurentii, Cryptococcus albidus, Candida parapsilosis, Candida albicans dan Candida tropicalis lebih berpotensi dibandingkan obat Aphotericin-B. Pada kelompok pengobatan dengan Nigella sativa terdapat satu penderita yang terdiagnosis otitis eksterna dengan penyebab infeksi jamur atau otomikosis, pasien mengeluh sudah hampir enam bulan mengeluh sakit telinga dan belum sembuh, setelah diberikan pengobatan dengan Nigella sativa pasien merasa nyaman dan tidak gatal namun saat evaluasi pada hari kelima pengobatan masih terdapat jamur ${ }^{19}$.

Dermatitis dapat terjadi pada pengobatan menggunakan salep Nigella sativa. Pengobatan minyak Nigella sativa secara topikal juga dapat menyebabkan terbentuknya bula serta nekrosis pada lapisan epidermis kulit setelah pemberian minyak selama dua minggu pada wanita berumur 53 tahun ${ }^{20,21}$.

\section{SIMPULAN}

Minyak Nigella sativa memiliki efektifitas pada pengobatan otitis eksterna tetapi tidak terdapat perbedaan yang bermakna jika dibandingkan dengan pengobatan menggunakan rivanol $0,1 \%$.

\section{DAFTAR PUSTAKA}

1. Hafil AF, Sosialisman, Helmi. (2011). Kelainan Telinga Luar. Soepardi EA, Iskandar N, Bashiruddin J, Restuti RD. Buku Ajar Ilmu Kesehatan Telinga Hidung Tenggorok Kepala \& Leher. Edisi ke-6.Jakarta: Badan penerbit FKUI; h. 60-3.

2. Mösges $\mathrm{R}$, Nematian-Samani $\mathrm{M}, \underline{\text { Hellmich }}$ $\underline{\mathrm{M}}$, Shah-Hosseini $\underline{\mathrm{K}}$. (2011). A meta-analysis of the efficacy of quinolone containing otics in comparison to antibiotic-steroid combination drugs in the local treatment of otitis externa. (10):2053-60

3. Guss J, Ruckenstein MJ. (2010). Infections of The External Ear. In: Flint PW, Haughey BH, Lund VJ, Niparko JK, Richardson MA, Robbins KT, et al. Cumming Otolaryngology Head \& Neck Surgery. 5rd ed. Philadelphia: Mosby elsevier; P. 1956-61.

4. Center for Disease Control and Prevention. Estimated Burden of Acute Otitis Externa United States, 2003-2007. Morbidity and Mortality Weekly Report. 2011;60:605-9.

5. Rowlands S, Devalia H, Smith C, Hubbard R, Dean A. (2011). Otitis externa in UK general practice: a survey using the UK General Practice Research Database. British Journal of General Practice, London.

6. Ardan, Juliarti, Satwika, Fian,Rosmana (2008), Otitis Eksterna. Dalam: Sinopsis Ilmu Kesehatan Telinga Hidung Tenggorokan. Bangka Belitung: Penerbit Buku Kedokteran AFJ

7. Patton R, Mukerji S, Francis B, Quinn Jr, Quinn MS. (2010). Pediatric Acute Infectious Otitis Externa. Grand Rounds Presentation, UTMB,Dept of Otolaryngology

8. Boies LR. (2012). Penyakit Telinga Luar. Adams GL, Boies LR, Higler PA. BOIES Buku Ajar Penyakit THT. Edisi ke-6. Jakarta: Penerbit buku kedokteran EGC; h. 75-80.

9. Soepardi EA, Iskandar N, Bashlruddin J, Restuti RD. (2014). Buku Ajar, Ilmu Kedokteran Telinga Hidung Tenggorok Kepala \& Leher (Edisi

Ketujuh). Fakultas Kedokteran Universitas Indonesia, hal.60-1.

10. Kedel IWM (2009). Hasil Guna Tampon Rivanol Dibanding Tampon Burowi Pada Penderita Otitis Eksterna Diffus Akut. Yogyakarta

11. Aftab Ahmad, Asif Husain, Mohd Mujeeb, Shah Alam Khan (2013). A review on therapeutic potential of Nigella sativa: A miracle herb Asian Pac J Trop Biomed 2013; 3(5): 337-352. 
12. Khalid, A., Ur-Rehman, U., Sethi, A., Khilji, S., Fatima, U., Khan, M.I., Waqas, M.K.,

Najam-us-Saqib, Q., Asad, M.H.H., Farzana, K., Mahmood, S., Waseem, A., Ismail, T., Murtaza, G. (2011). Antimicrobial activity analysis of extracts of Acacia modesta, Artimisia absinthium, N. sativa and Saussurea lappa against Gram positive and Gram negative microorganisms. African Journal of Biotechnology, 10(22): 4574- 4580.

13. Halawani,E. (2009). Antibacterial activity of Thymoquinone and Thymohydroquinone of $\mathrm{N}$. sativa L. and their interaction with some antibiotics. Advances in Biological Research 3(5-6): 148-152.

14. Ratnaningtyas, EA., Daya Hambat Ekstrak Jintan Hitam (Nigella sativa) terhadap Pertumbuhan Bakteri Plak, Skripsi, FKG Universitas Airlangga Surabaya, 2010.

15. Abu-Al-Basal, M.A., (2011). Influence of Nigella sativa fixed oil on some blood parameters and histopathology of skin in staphylococcalinfected BALB/c mice. Pak. J. Biol. Sci. 14 (23), 1038-1046

16. Harzallah, H., Grayaa, R., Kharoubi, W., Maaloul, A., Hammami, M. Mahjoub, T. $\quad$ (2012).

Thymoquinone, The Nigella sativa Bioactive Compound, Prevents Circulatory Oxidative Stress Caused by 1,2- Dimethylhydrazine Erythrocyte during Colon Post Initiation Carcinogenesis. Oxidative Medicine and Cellular Longevity. 2012, 6p. doi: $10.1155 / 2012 / 854065$.

17. Aljabre Salih H. M., Omar M. Alakloby, Mohammad A Randhawa, (2015). Dermatological effects of Nigella sativa. Journal of Dermatology \& Dermatologic Surgery doi: http://dx.doi.org/10.1016/j.jdds.2015.04.002.

18. Bashir MU, Qureshi HJ, Mumtaz U. 2014. Effect of Nigella sativa seeds extract on Serum C-reactive protein in albino rats. Annals. 20:35-39.

19. Rathi SG, Bhaskar VH, Raval BP, Suthar MP, Patel PG, Der Pharmacia Lettre, 2009, 1(2), 115120

20. Zedlitz S, Kaufmann R, Boehncke WH., 2002. Allergic contact dermatitis from black cumin (Nigella sativa) oil-containing ointment. Contact Dermatitis. 46:188.

21. Gelot P, Bara-Passot C, Gimenez-Amanu E et al., 2012. Bullous drug eruption with Nigella sativa oil. Ann Dermatol Venereol. 139(4):287-91 